\title{
Realisasi Kegiatan Program Daerah dalam Pengembangan Pembibitan Sapi Potong Guna Mendukung Swasembada Daging Nasional
}

\section{Realization of the Regional Programme for the Development of Beef Cattle Breeding To Support National Self-Sufficiency}

\section{Bambang Winarso}

\section{Pusat Sosial Ekonomi dan Kebijakan Pertanian, Bogor}

\begin{abstract}
Regional autonomy is given broad authority, real and accountable to local governments in proportion. In line with the local government should be able to utilize the potential of area resources optimally. However, under Regulation No 25 ps 2 verse 3, yr 2000 showed that specific authority perbibitan and arrangements regarding disease prevention remains a central government authority in this regard is Breed Livestock Directorate. Do with the efforts to develop livestock breeding cattle in various respo. In an effort to increase the population of cattle beef cattle , a policy that could be done by the East Java Provincial Government "Berlian" program. Meanwhile, Bali local government has declared Simantri Program, Jambi Provincial Government still relies on the center's programs, while in West Java are still doing investigations were the provinces that have the potential technical and non- technical support. This paper is part of the research results about the prospect of Livestock Breeding Beef Cattle Expansion medium scale done in 2012 by the Center for Economic and Social Agriculture . As for the location of the research done in the Province of Bali , East Java, West Java and Jambi Province
\end{abstract}

Keywords: Regional Programme, Beef Cattle Breeding, National Self-Sufficiency

Diterima: 16-04 2014, disetujui: 02-05-2014

\section{PENDAHULUAN}

Era reformasi memberikan peluang bagi perubahan cara pandang tentang pembangunan nasional dari pertumbuhan menuju pemerataan pembangunan secara lebih merata adil dan berimbang. Perubahan cara pandang ini antara lain diwujudkan melalui kebijakan otonomi daerah yang diatur dalam satu paket undang-undang yaitu Undang-undang no. 22 tahun 1999 tentang Pemerintah Daerah dan Undang-undang no. 25 tahun 1999 terutama tentang Perimbangan Keuangan Antara Pemerintah Pusat dan Daerah. Otonomi diberikan kepada daerah kabupaten/kota 
dilaksanakan dengan memberikan kewenangan yang luas, nyata dan bertangungjawab kepada pemerintah daerah secara proporsional. Sejalan dengan itu pemerintah daerah harus dapat mendayagunakan potensi sumberdaya daerah secara secara optimal.

Kaitannya dengan pengembangan sapi potong, pemerintah telah berupaya menciptakan swasembada daging sebanyak 3(tiga) kali yaitu pertama kebijakan swasembada daging yang dicanangkan pada periode 2000 - 2005 yang hasilnya belum memuaskan, kedua kebijakan swasembada daging yang dicanangkan pada periode tahun 2006 - 2010 yang hasilnya kurang menggembirakan dan ketiga pada periode 2010 -2014. Dalam upaya pencapaian Program Swasembada Daging, ada beberapa beberapa program pengembangan usaha budidaya ternak sapi potong yang dilaksanakan oleh pemerintah pusat. Program tersebut didalamnya termasuk pengembangan pembibitan dan jenis program yang dicanagkan diantaranya adalah Program Integrasi Tanaman-ternak (CLS/SIPT), program Sarjana Membangun Desa (SMD dan Program Lembaga yang telah Mengakar di Masyarakat (LM3).

Selama pelaksanakan program swasembada daging terutama daging sapi tersebut tidak sedikit peran pemerintah daerah dalam berupaya mendukung program tersebut diantaranya adalah kebijakan pengembangan pembibitan. Kebijakan perbibitan ternak sapi potong oleh pemerintah daerah melalui Dinas Peternakan Propinsi menunjukkan bahwa dalam upaya meningkatkan kinerja usaha perbibitan sebagai salah satu pilar untuk meningkatkan populasi ternak khususnya sapi potong masih ada beberapa permasalahan yang perlu mendapat perhatian diantaranya telah terjadi penurunan kwalitas ternak sapi potong khususnya ternak sapi potong jenis lokal.

Dengan adanya hal tersebut maka pemerintah daerah melalui Dinas Peternakan Propinsi telah melaksanakan beberapa program pengembangan ternak sapi potong diantaranya adalah Program penjaringan meliputi (a) Insentif dan Penyelamatan Betina Produktif dan (b) Pengendalian Sapi dan Kerbau Betina (Program tahun 2012). Realisasi pelaksanaan Program Pengendalian Sapi dan Kerbau Betina tersebut terdiri dari 2 kegiatan pokok yaitu (1) Penguatan modal kelompok terdiri dari 272 kelompok dimana masing-masing kelompok menerima bantuan dana sebesar Rp 200 juta/kelompok. (2) Penjaringan terdiri dari 78 kelompok, dimana pada tahun anggaran telah tersalurkan bantuan sebesar Rp 86,25 milyar sementara pada tahun 2012 turun menjadi Rp 40,3 Milyar yang telah disediakan oleh dana APBD I.

Secara metodologis tulisan ini merupakan bagian dari hasil penelitian tentang Prospek Pengembangan Pembibitan Ternak Sapi Potong Skala Menengah Dalam Upaya Mendukung Swasembada Daging Nasional yang dilakukan pada tahun 2012 oleh Pusat Sosial Ekonomi dan Kabijakan Pertanian Badan Litbang Pertanian. Adapun lokai penelitian di lakukan di beberapa wilayah provinsi diantaranya adalah Provinsi Bali, Jawa Timur, Jawa Barat dan Provinsi Jambi. Pola penyajian tulisan lebih diarahkan melihat kinerja usaha pengembangan pembibitan ternak sapi potong di masing-masing lokasi penelitian dan dengan menggunakan tabulasi silang sederhana sebagai alat analisisnya.

\section{PEMBAHASAN}

Pelaksanaan otonomi daerah telah membawa beberapa perobahan kinerja bagi pemda dalam rangka menjalankan hak otonominya. Salah satunya adalah semakin banyaknya produk hukum yang dibuat oleh pemda. Masalahnya adalah produk hokum yang dihasilkan ternyata sebagian besar berupa perda yang memungkinkan pemda untuk menarik sebanyak mungkin 
Bambang Winarso: Realisasi Kegiatan Program Daerah dalam Pengembangan Pembibitan Sapi Potong...

pungutan untuk meningkatkan PAD (Pendapatan Asli Daerah) (Anonimus, 2001). Hasil penelitian

Mayrowani dkk (2004) mengemukakan bahwa dalam tata niaga sapi potong terdapat beberapa macam retribusi diantaranya adalah (a) retribusi memasuki suatu wilayah daerah, (b) retribusi

kesehatan hewan, (c) retribusi di pasar hewan, (d) pungutan-pungutan di pos pemeriksaan

kesehatan hewan, (e) retribusi ternak di jembatan timbang, (f) retribusi penggunaan jalan, (g) pungutan-pungutan tak resmi oleh polisi, (h) retribusi pemotongan hewan dan retribusi kios daging.

Selain banyaknya produk hukum yang bermunculan, dampak otonomi daerah juga diwarnai oleh adanya keinginan provinsi memisahkan diri dari republik serta munculnya provinsi baru hasil pemekaran sebagai akibat adanya aspirasi dan tuntutan masyarakat terutama pada awalawal pelaksanaan otonami daerah (Argama, 2005). Tuntutan tersebut sebagian dilatarbelakangi oleh kekaayaan alam yang dimiliki daerah. Sementara Solly Lubis (2003) mengemukakan bahwa bagi pemerintah pusat, sumber kekayaan yang ada di daerah adalah merupakan bagian penting bagi penghasilan nasional yang dihasilkan oleh suatu daerah dan tidak bisa hanya digunakan untuk kepentingan daerah yang bersangkutan. Azaz pemerintahan pusat menunjukkan bahwa kekayaan yang ada di daerah tertentu juga dibagi-bagikan ke daerah lain. Akibatnya kekayaan suatu daerah tidak dapat dinikmasi oleh daerah yang bersangkutan. Sementara pandangan daerah adalah sebaliknya, namun membawa akibat terhadap daerah yang wilayahnya miskin akan semakin miskin.

Kaitannya dengan masalah sapi potong terutama dalam hal pembibitan sapi potong, Samariyanto, 2004 mengemukakan bahwa era otonomi daerah yang digulirkan sejak tahun 1999, berdasarkan PP No 25 ps 2 ayat 3, thn 2000 menunjukkan bahwa kewenangan khusus menyangkut perbibitan dan pengaturan pencegahan penyakit masih menjadi kewenangan pemerintah pusat. Untuk itu Direktorat Perbibitan memiliki peranan yang stratgis dalam pembinaan/bimbingan, pengawasan, fasilitasi dan pengaturan terhadap (a) pembibitan ternak rakyat dipedesaan, (b) pembibitan ternak swasta dan (c) pembibitan ternak pemerintah.

Sejalan dengan itu maka dari hasil pengamatan dilapangan terutama di empat lokasi contoh kinerja pengembangan usaha ternak sapi potong maka keragaan pengembangan sapi potong utamanya kaitannya dengan usaha pembibitan di daerah menunjukkan kinerja yang beragam sebagai berikut:

\section{Kasus Jawa Timur}

Dalam upaya meningkatkan populasi ternak sapi potong, kebijakan yang ditempuh oleh Pemerintah Provinsi Jawa Timur, melalui Dinas Peternakan Provinsi Jawa Timur telah pencanangkan program "Berlian” (Beranak Lima Juta Ekor Dalam Satu Tahun) yang juga merupakan program daerah Propinsi Jawa Timur dalam rangka mendukung program swasembada daging. Melalui program tersebut yang khusus menekankan pada intensitas IB, hal ini berarti bahwa peran daerah terutama wilayah-wilayah yang termasuk dalam kategori sentra pengembangan ternak sapi potong sudah selayaknya dikembangkan tidak saja di wilayah-wilayah yang telah berkembang, akan tetapi purlu juga dikembangkan di wilayah propinsi potensial lainnya.

Program IB yang dicanangkan oleh pemerintah Propinsi Jawa Timur berdampak positip sekaligus negatif. Dampak positif adalah mampu meningkatkan populasi ternak dan mampu meningkatkan produksi daging ternak sapi potong. Mengingat permintaan IB yang cukup tinggi. Dampak negatifnya adalah bahwa tingginya permintaan IB ditingkat peternak belum dibarengi dengan kesiapan informasi terhadap masyarakat akan bahaya kepunahan sumberdaya genetik sapi local. Hal ini disebabkan karena masyarakat peternak dalam hal kegiatan IB sudah mengarah pada 
brended minded yaitu Cross Breed Sement yaitu semen dari jenis jantan impor seperti Simental dan Limousin. Tingginya permintaan peternak terhadap jenis semen tersebut cenderung meningkatnya jumlah populasi ternak hasil-hasil crossing yang dapat menggeser keberadaan ternak lokal. Dikhawatirkan ternak sapi potong hasil-hasil persilangan suatu ketika tingkat produktifitasnya rendah.

Kegiatan yang berkaitan dalam upaya peningkatan populasi ternak sapi potong di wilayah Propinsi Jawa Timur adalah kegiatan peningkatan populasi Sapi Madura. Sapi Madura merupakan bangsa sapi asli dari wilayah Madura yang telah ditetapkan sejak pemerintah kolonial Belanda pada tahun 1934. Peraturan tersebut tertuang dalam Staatsblad (lembaran negara) No.226/1923 dan No.57/1934 serta No.115/1937 (Sumber: Dinas Peternakan Propinsi Jawa Timur, 2011). Pemerintah telah melakukan kegiatan peningkatan populasi Sapi Madura dimulai sejak Thn 2009 yang bertujuan (a) Pelestarian dan pengembangan plasma nutfah Sapi Madura, (b) Pengembangan kawasan sentra Pembibitan Sapi Madura, dan (c) Pemberdayaan masyarakat.

Kegiatan utama yang dilakukan adalah pengembangan kawasan sentra pembibitan Sapi Madura yang berbasis pada kawasan VBC (Village Breeding Centre) yang mana kegiatan IB dengan menggunakan semen beku asal Sapi Madura dan Kawin alam merupakan hal yang diprioritaskan. Melalui Ketetapan Menteri Pertanian No.3755/KPts/HK.040/11/2010 telah diusulkan bahwa keberadaan Sapi Madura sebagai kekayaan plasmanutfah milik Indonesia yang diakui dunia internasional dan diharapkan tidak lagi diklaim oleh negara lain.

Hasil sensus tahun 2011 jumlah populasi ternak sapi potong di wilayah Provinsi Jawa Timur berkisar 4,7 juta ekor, dimana dari besaran angka tersebut diperkirakan sapi yang masih murni lokal diperkirakan sekitar 30\% (angka ini masih diragukan), hal ini diakarenakan hasil sensus tidak mendeteksi kemurnian asal sapi tersebut, tetapi hanya sapi berdasarkan jenisnya. Kasus pengiriman ribuan ekor sapi Madura ke Malaysia perlu diwaspadai, disamping itu dengan semakin derasnya IB ke pulau Madura, juga menjaga kemurnian jenis sapi Madura. Pemerintah telah merencanakan Pulau Sapudi sebagai wilayah pemurnian sapi Jenis Madura. Hal ini akan dilakukan penjaringan terhadap sapi Madura yang ada di Pulau Sapudi sebanyak 10.000 ekor induk produktif. Diperkirakan populasi sapi di wilayah Pulau Sapudi tidak kurang dari 45.000 ekor. Untuk mempertahankan keberadaan sapi Madura, maka di wilayah Pulau Madura telah dilakukan kontes karan sapi maupun Sapi Sonok yang dimaksudkan untuk mempertahankan kemurnian sapi jenis tersebut. Sapi Madura apabila dipelihara dengan baik maka berat badannya dapat mencapai $600 \mathrm{~kg}$. Disisi lain menunjukkan bahwa ketertarikan peternak untuk memelihara sapi BX terutama Limosin dan Simental yang dari aspek ekonomi memang lebih menguntungkan. Dampak negatifnya adalah bahwa tingginya permintaan IB ditingkat peternak belum diimbangi dengan kesiapan masyarakat akan bahaya kepunahan sumberdaya genetik sapi lokal. Tingginya permintaan peternak terhadap jenis semen tersebut cenderung meningkatnya jumlah populasi ternak hasil-hasil crossing yang dapat menggeser keberadaan ternak lokal itu sendiri. Dikhawatirkan kalau ternak sapi potong hasil crossing suatu ketika tingkat produktifitasnya rendah dan dapat mengganggu pertumbuhan populasi yang diharapkan. Untuk itu, diperlukan tindakan pencegahan secara konseptual oleh pemerintah dengan fokus pada daerah-daerah yang relatif sesuai agroekosistemuntuk sapi lokal, khususnya untuk sapi Peranakan Ongol dan sapi Madura.

\section{Kasus Propinsi Bali}

Secara administratif Provinsi Bali terdiri dari 8 (delapan) kabupaten dan 1(satu) kota dengan 57 kecamatan, 715 desa dan pada tahun 2011 jumlah populasi ternak sapi bali diwilayah ini 
Bambang Winarso: Realisasi Kegiatan Program Daerah dalam Pengembangan Pembibitan Sapi Potong...

sekitar 637.473 ekor. Jika dibandingkan dengan jumlah populasi ternak sapi bali tahun 2010, tahun 2011 mengalami peningkatan sebesar 6,77\%. Keragaan perkembangan jumlah pupolasi ternak sapi potong selama 5(lima) tahun terakhir (2007 - 20011) di wilayah Provinsi Bali tahun 2011 disajikan dalam tabel 1.

Tabel 1 Perkembangan Gapoktan Yang mendapat Bantuan Program Simantri Thn 2009 - 2011

\begin{tabular}{|c|c|c|c|c|c|c|c|c|c|c|}
\hline \multirow[b]{2}{*}{ INo } & \multirow[b]{2}{*}{ napupaten } & \multicolumn{3}{|c|}{2009} & \multicolumn{3}{|c|}{2010} & \multicolumn{3}{|c|}{2011} \\
\hline & & $\mathbf{A}$ & B & $\mathbf{C}$ & $\mathbf{A}$ & B & $\mathbf{C}$ & $\mathbf{A}$ & B & $\mathbf{C}$ \\
\hline 1 & Denpasar & 0 & 0 & 0 & 1 & 169.5 & $\operatorname{tad}$ & 2 & 400 & tad \\
\hline 2 & Badung & 1 & 176 & 20 & 1 & 169,5 & $\operatorname{tad}$ & 4 & 800 & $\operatorname{tad}$ \\
\hline 3 & Gianyar & 1 & 176 & 20 & 2 & 339 & $\operatorname{tad}$ & 14 & 2800 & $\operatorname{tad}$ \\
\hline 4 & Klungkung & 0 & 0 & 0 & 3 & 508.5 & tad & 17 & 3400 & $\operatorname{tad}$ \\
\hline 5 & Kr. Asem & 1 & 176 & 20 & 8 & 1356 & $\operatorname{tad}$ & 17 & 3400 & $\operatorname{tad}$ \\
\hline 6 & Bangli & 1 & 176 & 20 & 6 & 1017 & $\operatorname{tad}$ & 12 & 2400 & $\operatorname{tad}$ \\
\hline 7 & Buleleng & 4 & 646 & 75 & 13 & 2034 & $\operatorname{tad}$ & 18 & 3600 & $\operatorname{tad}$ \\
\hline 8 & Jembrana & 1 & 176 & 20 & 2 & 339 & $\operatorname{tad}$ & 6 & 1200 & $\operatorname{tad}$ \\
\hline 9 & Tabanan & 1 & 176 & 20 & 4 & 678 & $\operatorname{tad}$ & 10 & 2000 & $\operatorname{tad}$ \\
\hline
\end{tabular}

Ket : A= Jumlah kelompok, B= Jumlah Bansos (Rp Juta); C= Jumlah bantuan ternak yang diterima (ekor) Sumber: Dinas Peternakan dan Kesehatan Hewan Prov. Bali, Thn 2011.

Dalam upaya pengembangan populasi ternak sapi potong, pemerintah daerah Provinsi Bali sejak tahun 2009 telah mencanangkan Program Pengembangan Usaha Pertanian Terintegrasi (Simantri). Program yang didukung oleh SK Gubernur No. 1776 Thn 2011 tersebut adalah merupakan sistem pertanian integrasi sebagai kelanjutan dari program Prima Tani dari Badan Litbang Pertanian/BPTP. Pertanian terintegrasi memadukan kegiatan pertanian dalam arti luas dalam satu kawasan sesuai potensi wilayah dengan diversifikasi usaha baik secara vertikal maupun horizontal dengan dukungan sektor terkait lainnya diluar sektor pertanian sehingga dapat terbangun usaha agribisnis di wilayah yang bersangkutan.

Dalam kegiatan tersebut tidak terkecuali adalah pengembangan ternak sapi potong khusunya usaha pembibitan. Arah program pembibitan ini adalah termasuk pelestarian sapi Bali yang diharapkan dapat memberikan insentif lebih baik bagi peternak, dengan mengedepankan perkawinan dilakukan dengan cara IB. Pada awal kegiatan Simantri tahun 2009, kegiatan pengembangan peternakan mendapatkan bantuan dana alokasi Bansos sebesar Rp 1,7 milyar yang dipergunakan untuk pengadaan bibit sapi betina sebanyak 195 ekor, kambing 4 ekor yang dialokasikan di 10(sepuluh) Gapoktan. Disamping bibit ternak tersebut juga dialokasikan dalam bentuk kandang sapi koloni 9 (Sembilan) unit, kandang kambing 1(satu) unit, instalasi biogas dan pengolahan pakan 9 unit untuk 9 Gapoktan, instalasi bio urine dan pengolah kompos sebanyak 9 (Sembilan) unit.

Pada tahun 2010 bantuan tersebut meningkat menjadi Rp 6,77 milyar yang dialokasikan untuk pengadaan bibit sapi betina sebanyak 760 ekor, kambing pejantan sebanyak 8 (delapan) ekor, kambing betina sebanyak 80 ekor, kandang sapi koloni sebanyak 38 unit, kandang kambing koloni sebanyak 2 (dua) unit, instalasi bio gas sebanyak 40 unit, kantong bio gas $1 \mathrm{~m}^{3}$ sebanyak 200 unit dan instalasi biourine sabanyak 40 unit. Pada tahun anggaran 2011 program tersebut mendapat alokasi dana APBD sebesar Rp 23,17 milyar dimana dana sebesar Rp 20,0 milyar merupakan dana Bansos. Dana dari Bansos sebesar Rp 7,68 milyar khusus diperuntukkan untuk pengembangan bibit 
sapi betina sebanyak 1920 ekor sementara sisa dana lainnya diperuntukkan untuk pembangunan bidang peternakan lainnya. (Tabel 1).

Bali merupakan sentra pengembangan ternak sapi Jenis Sapi Bali, dimana populasi induk saat ini sebanyak 250.000 ekor. Dengan populasi induk sebanyak tersebut diharapkan Bali dapat mensuport bibit sapi Bali sebanyak 15.000 ekor pertahun. Saat ini pemerintah Propinsi Bali sedang merencanakan wilayah ini sebagai sentra industri ternak sapi bibit. Sehingga kebutuhan nasional akan bibit salah satunya dapat dipasok dari Bali. Dalam upaya mendukung kebijakan tersebut Pemerintah Daerah Propinsi Bali sedang mencanangkan Program "Simantri” yang diarahkan bahwa kegiatan pengembangan ternak sapi diwilayah ini diarahkan ke indistri pembibitan ternak sapi.

Program tersebut merupakan program pembibitan yang tetap mengandalkan peternakan rakyat sebagai tulang-punggung kegiatan, yang didukung oleh pengembangan kelembagaan kelompok tani ternak maupun Gabungan kelompok tani-ternak. Diharapkan dengan berkembangnya peternak rakyat tersebut diwilayah Bali tidak lagi diharapkan adanya peran investor yang bergerak dibidang pengembangan pembibitan ternak sapi potong. Dengan berkembangnya peternak-peternak rakyatlah yang diharapkan dapat mendukung kebutuhan bibit sapi nasional.

Dalam upaya mendukung kebijakan "Simantri" yang sebenarnya merupakan kebijakan Pemerintah Daerah (Gubernur) tersebut, Dinas Peternakan Provinsi Bali telah berupaya membentuk peternak dalam memasarkan ternak bibit bakalan. Dimana kebijakan Dinas Peternakan dalam pemasaran bibit bakalan tersebut diharapkan melalui satu pintu yaitu Dinas Peternakan Tingkat Propinsi. Sehingga keluarnya bibit sapi bakalan tersebut disamping dapat terkontrol juga ada jaminan kwalitas yang bisa dipertangung-jawabkan. Bentuk kebijakan yang dicanagkan oleh Dinas peternakan Propini Bali tersebut disamping adanya kebijakan satu pinti juga adanya kebijakan penentuan harga bibit bakalan, dimana harga satu ekor bibit bakalan dengan ukuran tinggi badan $105 \mathrm{~cm}$ dipatok dengan harga $\mathrm{Rp}$ 6.000.000/ekor.

Tujuan kebijakan tersebut diharapkan dapat merangsang peternak untuk lebih giat dalam mengembangkan usaha budidaya ternaknya khususnya dalam budidaya pembibitan. Akan tetapi kebijakan tersebut tampaknya tidak efektif. Sebab harga sapi bibit ukuran tinggi $105 \mathrm{~cm}$ dengan harga Rp 6000.000/ekor dirasa sangat mahal oleh konsumen. Sehingga kontrak-kontrak jual beli yang pernah dirintis dengan beberapa wilayah pembeli terutama dari Kalimantan Timur, Kalimantan Barat dan lokasi lainnya menemui kegagalan. Dimana pembeli cenderung melakukan transaksi langsung dengan melalui pedagang ternak yang harganya lebih murah.

Wilayah Propinsi Bali sebenarnya sudah merupakan wilayah yang cukup berkembang dalam budidaya ternak sapi potong. Sebagai salah satu sentra pengembangan ternak sapi potong wilayah ini tetap berusaha untuk meningkatkan populasi ternak dengan berbagai upaya, yang salah satunya adalah peningkatan peran inseminasi buatan. Akan tetapi kondisi riil dilapangan menunjukkan bahwa sebagai pemasok bibit wilayah Bali saat ini sedang menghadapi beberapa permasalahan diantaranya adalah: (a) Keterbatasan wilayah, artinya wilayah Propinsi Bali yang hanya merupakan wilayah yang sudah sulit untuk dijadikan areal pengembangan ternak sapi potong, hal ini ditunjang oleh kepadatan ternak yang juga semakin padat. (b) Sulitnya pengembangan usaha pembibitan ternak sapi potong diwilayah ini utamanya adalah karena keterbatasan wilayah pertanian sebagai pemasok utama limbah pertanian yang dapat dimanfaatkan sebagai pakan ternak. Pada wilayah-wilayah tertentu kekurangan pakan tersebut dirasa sudah sangat serius. (c) Pemerintah selama ini belum menghargai bibit ternak sapi potong. Artinya selama 
Bambang Winarso: Realisasi Kegiatan Program Daerah dalam Pengembangan Pembibitan Sapi Potong...

ini peran pemerintah dalam pengembangan usaha pengadaan bibit belum banyak dilakukan baru sebatas penyediaan strow semata. Sedangkan apabila bibit tersebut telah berhasil diciptakan maka harganya tidak seberapa. Dengan rentabilitas usaha yang tergolong rendah sementara harga bibit tidak menjamin (murah) maka sulit diharapkan usaha pembibitan dapat berkembang secara maksimal. Informasi tentang perkembangan populasi Sapi Bali di Propinsi Bali Selama Thn 2007 2011 ditampilkan dalam Tabel 2.

Tabel 2 : Perkembangan Populasi Sapi Bali di Propinsi Bali Selama Tahun 2007 - 2011

\begin{tabular}{|c|c|c|c|c|c|c|c|c|c|c|c|}
\hline \multirow[b]{2}{*}{ nabupaten } & \multicolumn{4}{|c|}{ Jantan } & \multicolumn{5}{|c|}{ Dewasa (tahun) } & \multirow[b]{2}{*}{ summan } & \multirow[b]{2}{*}{ Jumian } \\
\hline & Anak & Muda & Dewasa & juml & Anak & Muda & $2-4$ & $5-6$ & $>6$ & & \\
\hline Denpasar & 970 & 485 & 319 & 1774 & 1180 & 737 & 1263 & 1412 & 1813 & 6405 & 8179 \\
\hline Badung & 4007 & 6279 & 6642 & 16928 & 4769 & 7190 & 7775 & 8062 & 3325 & 31121 & 48049 \\
\hline Gianyar & 6276 & 7517 & 5429 & 19222 & 5572 & 5567 & 7529 & 6287 & 3105 & 28060 & 47282 \\
\hline Klungkung & 5157 & 3972 & 2558 & 11687 & 6001 & 5361 & 7182 & 9975 & 6409 & 34928 & 46615 \\
\hline Kr. Asem & 10201 & 20910 & 20228 & 51339 & 11440 & 16870 & 19641 & 25891 & 10326 & 84168 & 135507 \\
\hline Bangli & 8136 & 22847 & 21529 & 52512 & 6648 & 12797 & 10916 & 8049 & 3141 & 41551 & 94063 \\
\hline Buleleng & 14236 & 20430 & 12867 & 47533 & 12133 & 19365 & 22443 & 22852 & 11863 & 88656 & 136189 \\
\hline Jembrana & 4436 & 958 & 861 & 6255 & 7448 & 5843 & 10508 & 14884 & 9839 & 48522 & 54777 \\
\hline Tabanan & 6874 & 12446 & 11654 & 30974 & 5397 & 7083 & 9176 & 10079 & 4103 & 35838 & 66812 \\
\hline Jumlah 2011 & 60293 & 95844 & 82087 & 238224 & 60588 & 80813 & 96433 & 107491 & 5353924 & 399249 & 637473 \\
\hline Jumlah 2010 & 89482 & 101287 & 94813 & 285582 & 86354 & 96370 & & & 398164 & 398164 & 683800 \\
\hline Jumlah 2009 & 89065 & 102823 & 94727 & 286615 & 85386 & 92340 & & & 388645 & 388645 & 675419 \\
\hline Jumlah 2008 & 88418 & 101752 & 90974 & 281144 & 84499 & 93837 & & & 385696 & 385696 & 668065 \\
\hline Jumlah 2007 & 82951 & 96985 & 87466 & 267402 & 78502 & 87045 & & & 365525 & 365525 & 633789 \\
\hline
\end{tabular}

Sumber: Dinas Peternakan Propinsi Bali, thn 2012

\section{Kasus Provinsi Jambi}

Hasil penelitian di wilayah Provinsi Jambi menunjukkan bahwa kegiatan pengembangan peternakan di Provinsi Jambi sebagian besar masih dikelola oleh peternak sebagai usaha sampingan yang dilakukan oleh peternak-peternak yang memiliki kebun sawit maupun oleh mereka-mereka yang tidak memiliki kebun sawit akan tetapi peran utamanya adalah sebagai buruh kebun sawit atau buruh lainnya. Pola pemeliharaan yang dilakukan umumnya dilakukan secara ekstensif maupun semi intensif dengan penguasaan ternak sekitar 5 - 15 ekor/peternak. Pola usaha seperti ini sesungguhnya dapat meningkatkan pendapatan rumahtanga peternak karena biaya tenaga untuk pengelolaan ternak tidak perlu dikeluarkan.

Kebutuhan tenaga kerja pengelolaan ternak cukup dipenuhi dengan memanfaatkan tenaga kerja keluarga. Hanya saja, pola pengembangan seperti ini cenderung kurang memacu peternak untuk meningkatkan produktivitas ternaknya sehingga peternak kurang terdorong untuk meningkatkan kemampuannya, baik dalam hal teknis pemeliharaan ternak maupun manajemen usahataninya. Peran pemerintah terutama lembaga penyuluhan dalam pengembangan usaha peternakan sangat penting terutama dalam hal pembinaan baik pembinaan teknis maupun non teknis. Fakta yang ada saat ini peran kelompotani ternak di wilayah Program Integrasi terutama di Propinsi Jambi secara umum belum berkembang dengan baik sehingga peternak cenderung berusahatani-ternak tidak dalam suatu kelembagaan yang kuat tetapi dilakukan secara perorangan. Keadaan seperti ini tentunya akan mempersulit upaya instansi teknis dalam membina peternak. 
Selain itu, kemampuan peternak untuk melakukan negosiasi dengan pihak lain, seperti halnya lembaga penyedia modal, masih lemah.

Pada tahun 2012, beberapa program yang sedang dilaksanakan di Bidang Budidaya Dinas Peternakan Propinsi Jambi diantaranya adalah (a) Program Penjaringan Betina Produktif yang merupakan kelanjutan dari Program Penyelamatan Betina Produktif yang dilakukan pada thn anggaran 2011. (b) Program Penambahan Induk Sapi Potong sebanyak 409 ekor yang rencananya akan di sebar di 7 wilayah kabupaten yang mana kegiatannya saat ini masih dalam proses tender.

(c) Pengadaan pejantan pemacek sebanyak 50 ekor. Dari sapi betina sebanyak 409 ekor dan pejantan sebanyak 50 ekor tersebut semuanya merupakan sapi Jenis Sapi Bali. Propinsi Jambi merupakan wilayah propinsi yang kekurangan ternak sapi potong. Kebutuhan pertahun rata-rata 32.000 ekor, sementara kemampuan penyediaan baru 22.000 ekor, artinya masih ada kekurangan ternak sapi potong sebesar 10.000 ekor per tahun. Dalam upaya peningkatan populasi ternak sapi potong pemerintah daerah setempat khususnya melalui Dinas Peternakan Provinsi Jambi telah mendapat alokasi anggaran tahun 2012 sebesar Rp 22 milyar.

Besarnya populasi ternak sapi potong diwilayah Propinsi Jambi (2012) adalah sebanyak 119.888 ekor yang tersebar di 14 kabupaten/kota. Apabila jumlah populasi yang ada tersebut dikaitkan dengan potensi wilayah Propinsi Jambi dalam hal pengembangan populasi ternak sapi potong, maka jumlah tersebut masih sangat kecil, mengingat potensi wilayah Propinsi jambi disamping luas juga kaya akan limbah pertanian maupun hijauan lainnya. Potensi besar seperti luas areal perkebunan sawit sekitar 489.384 ribu ha (2009) dengan produksi sebesar 1,26 juta ton, perkebunan kakao seluas 1.324 ha, luas areal perkebunan kopi seluas 24,92 ribu ha dengan jumlah produksi sekitar 12,73 ton, sementara luas areal pertanian tanaman pangan khsusnya padi seluas 153, 89 ribu ha dengan tingkat produksi sebesar 628, 82 ribu ton (2010) merupakan potensi besar untuk pengembangan ternak sapi potong di Propinsi Jambi. Dalam upaya peningkatan populasi ternak sapi potong, peran perusahaan swasta terutama yang bergerak dibidang industri minyak sawit, pertambangan dan dibidang pulp, perusahaan-perusahaan tersebut sebagian telah berpartisipasi dalam pengembangan populasi ternak sapi melaui bantuan CSR (Corporate Social Responsibility).

Dalam upaya pengembangan populasi ternak sapi potong, pemerintah daerah setempat dan pemerintah pusat telah mengembangkan Program Integrasi Sawit-Sapi potong, dimana jenis sapi yang banyak dikembangkan adalah Sapi Bali. Alasan banyak dikembangkannya Sapi Bali Jenis sapi tersebut banyak diminati oleh masyarakat karena (a) mudah beradaptasi, (b) pemeliharaan tidak terlalu sulit terutama dalam hal ketersediaan pakan, (c) dagingnya lebih diminati daripada daging jenis sapi PO maupun Brahman dan (d) harganya relatif murah dan terjangkau apabila petani mau mengadakan ternak sapi tersebut. Pada tahun 2007 Pemerintah Pusat melalui Ditjend Peternakan dan Kesehatan Hewan pernah melakukan pengiriman sapi Jenis Brahman, akan tetapi program tersebut gagal, sebab sapi tidak bisa berkembang biak.

Kasus di wilayah Propinsi Jambi menunjukkan bahwa dalam upaya pengembangan ternak sapi potong, peran swasta sudah mulai tampak. Saat penelitian ini dilakukan, PTP VI sedang melakukan pengadaan sapi jenis Bali sebanyak 2000 ekor, pola pemeliharaannya adalah masih dalam upaya penggemukan dan dikelola secara manajemen perkebunan, artinya sapi tersebut tidak dikelola secara berkelompok, melainkan dikelola oleh manajemen perusahaan PTP.

Menurut informasi sumber anggaran untuk pengadaan sapi tersebut sebenarnya merupakan anggaran yang diperuntukkan bagi kegiatan CSR (Corporate Social Responsibility) perusahaan. Akan tetapi pengelolaan kegiatan peternakan tersebut bukannya diserahkan kepada para peternak 
Bambang Winarso: Realisasi Kegiatan Program Daerah dalam Pengembangan Pembibitan Sapi Potong...

sekitar perusahaan akan tetapi dikelola sendiri oleh perusahaan. Dalam hal pengadaan pakan ternak, melimpahnya limbah sawit sampai saat ini belum sepenuhnya dapat dimanfaatkan secara keseluruhan terutama pemanfaatan pelepah sawit. Hal ini disebabkan terbatasnya alat/mesin coper sebagai pencacah pelepah sawit tersebut.

Sumber daya alam untuk mendukung pengembangan peternakan di Provinsi Jambi masih cukup tersedia dalam jumlah besar. Salah satu sumberdaya yang potensial adalah berbagai hasil ikutan dari usahatani perkebunan yang dapat dimanfaatkan sebagai sumber pakan ternak ruminansia terutama sapi potong. Hasil ikutan tersebut dapat berupa hijauan antar tanaman perkebunan, limbah tanaman seperti pelepah kelapa sawit dan limbah hasil industri perkebunan sawit seperti lumpur dan bungkil kelapa sawit. Dengan membandingkan populasi ternak yang ada di Provinsi Jambi yang saat ini terhadap areal perkebunan yang tersedia maka masih terdapat peluang yang sangat besar bagi provinsi ini untuk mengembangkan usaha peternakan.

Hal serius yang dihadapi oleh kelompok peternak adalah lemahnya penguasaan modal, sehingga perlu bantuan kredit berbunga lunak. Masalah yang perlu dicarikan pemecahannya adalah bagaimana agar kegiatan usaha pemeliharaan sapi potong, terutama dalam usaha perbibitan dapat berjalan efektif, sehingga bisa memberikan pendapatan layak. Disamping dapat memberikan hasil tambahan bagi setiap anggota kelompok, bagi yang meminjam dana dari program kredit, seperti KUPS, KUR, KKPE dll, maupun jenis kredit komersial lainnya, pendapatan itu juga dapat untuk mencicil pinjaman. Keterbatasan modal menjadi penghalang bagi peternak untuk menambah skala usaha.

Salah satu kasus yang erat hubungannya dengan masalah permodalan adalah kebutuhan modal bagi peternak di areal perkebunan kelapa sawit yang saat ini sedang dihadapkan pada masalah replanting tanaman sawit. Saat replanting dilakukan, kesulitan ekonomi keluarga pasti terjadi, karena terbatasnya pendapatan. Pemerintah diharapkan membantu modal untuk pengadaan ternak, terutama bagi petani sawit yang belum memiliki ternak. Hal ini sebagai pengganti usaha saat replanting tanaman tersebut dilakukan. Diperlukan waktu empat tahun lamanya bagi petani untuk menunggu sebelum tanaman sawit yang baru mulai panen.

Berdasarkan hasil Laporan Tahunan Dinas Peternakan Provinsi Jambi Tahun 2010 menunjukkan bahwa melalui dana tugas pembantuan APBN-P 2010 telah dialokasikan dana bantuan sosial untuk pengembangan pembibit sapi. Dana yang tersebut disalurkan kepada delapan kelompok tani dengan nilai masing-masing Rp 435.000.000,- Sampai dengan akhir tahun 2010 seluruh dana yang tersedia telah ditransfer ke rekening kelompok, walaupun belum semua kelompok dapat memanfaatkan bantuan tersebut seluruhnya karena penyaluran dana kepada kelompok baru dapat dilaksanakan pada bulan Dessember 2010. Nama kelompok penerima dana bansos pembibitan sapi dana APBN-P disajikan pada Tabel 3.

Sementara itu dalam rangka upaya penguatan modal usaha kelompok (PMUK) untuk Integrasi Sapi Sawit di wilayah Propinsi Jambi, juga telah dirintis mulai sejak tahun 2007, dimana Dinas Perkebunan memulai kegiatan integrasi di Provinsi Jambi, berlanjut sampai tahun 2008. Sejak tahun 2009 kegiatan integrasi berada pada Dinas PKH Provinsi Jambi, sedangkan pengadaan sarana dan prasarana berada pada Dinas Perkebunan. Lokasi yang disepakati kedua instansi berada pada tiga kabupaten yaitu Tanjung Jabung Barat, Batanghari dan Muaro Jambi. Disamping itu pada tahun 2010 Direktorat Jenderal Peternakan melalui dana Tugas Pembantuan Pusat juga mengalokasikan dana kegiatan integrasi pada dua kabupaten yaitu Muaro Jambi dan Tebo. 
Jurnal Penelitian Pertanian Terapan

Tabel 3 Kelompok Ternak Penerima Bantuan Sosial (Bansos) Pembibitan SapiAPBN-P, 2010.

\begin{tabular}{lllll}
\hline \multirow{2}{*}{ No } & \multicolumn{1}{c}{ Nama Kelompok } & \multicolumn{3}{c}{ Lokasi } \\
\cline { 3 - 5 } & & Desa & Kecamatan & Kabupaten/ Kota \\
\hline 1 & Sido Mulyo II & Ciledong & Pemayung & Batanghari \\
2 & Permadani & Mukai Pintu & Pelepat & Bungo \\
3 & Tunas Harapan & Rawa Jaya & Tabir Selatan & Kerinci \\
4 & Suka Tani & Kebun IX & Sungai Gelam & Muaro Jambi \\
5 & Tunas Jaya II & Sei. Gedang & Singkut & Sarolangun \\
6 & Suka Maju & Purwodadi & Tebing Tinggi & Tanjab Barat \\
7 & Sumber Rezeki & Sei. Tering & Nipah Panjang & Tanjab Timur \\
8 & Harapan Makmur & & & \\
\hline
\end{tabular}

Salah satu hambatan petani dalam pengembangan ternak adalah kesulitan dalam mendapatkan modal terutama untuk pembelian ternak. Berdasarkan informasi dari Dinas Peternakan Propinsi Jambi bahwa untuk mengatasi masalah tersebut maka Dinas PKH Provinsi Jambi telah melakukan kerjasama dengan PT Jamsostek dan PT Perkebunan Nusantara VI dalam penyediaan modal untuk pengadaan ternak sapi. Kerjasama dengan PT. Jamsostek pada tahun 2010 dilakukan melalui penyediaan modal dengan bunga lunak sebesar 6\% pertahun dengan jangka waktu pelunasan selama dua tahun untuk pengadaan bibit sapi di Kabupaten Tanjung Jabung Barat.

Dana yang disalurkan diberikan sebanyak Rp 480.000.000 yang digunakan untuk pengadaan bibit sapi masing-masing sebanyak 50 ekor untuk petani di SP 8 Bukit Indah,

Kecamatan Ma. Papalik dan 14 ekor untuk petani di SP 1 Desa Lampisi, Kecamatan Merlung.

Kerjasama dengan PT. Perkebunan Nusantara VI pada tahun 2010 dilaksanakan berupa pemanfaatan dan dana CSR (Corporate Social Reponsibility) untuk pengadaan sapi bibit sebanyak 60 ekor. Sapi tersebut disebarkan pada lokasi plasma PT. Perkebunan Nusantara VI, yaitu di Bukit Kausar Kabupaten Tanjung Jabung Barat sebanyak 20 ekor; Rimbo 1 dan Rimbo 2, Kabupaten Tebo masing-masing sebanyak 20 ekor.

\section{Kasus Provinsi Jawa Barat}

Hasil evaluasi terhadap pembangunan di wilayah Provinsi Jawa Barat menunjukkan bahwa perkembangan capaian pembangunan provinsi Jawa Barat dilihat dari dua belas isu strategis dan kebijakan pembangunan daerah tahun 2012 salah satu isu strategis tersebut adalah peningkatan ketahanan pangan yang direspon melalui kebijakan pembangunan peternakan diantaranya adalah upaya peningkatan produksi satu juta ekor sapi potong dan sapi perah serta sepuluh juta ekor kambing/domba (Badan Perencanaan Pembangunan Daerah Provinsi Jawa Barat, 2012).

Dalam hal pengembangan pembibitan sapi potong, kasus di Jawa Barat menunjukkan bahwa masih diperlukan penjajakan terhadap wilayah-wilayah potensial yang memiliki dukungan teknis maupun non teknis. Dalam upaya pengembangan wilayah yang didalamnya juga termasuk sektor peternakan, maka program yang ada dikenal dengan naman Program Ciayu Maja Kuning (Cirebon, Indramayu, Majalengka dan Kuningan) yang merupakan pengembangan wilayah bagian utara Jawa barat, sementara selama ini untuk ternak sapi potong konsentrasi pengembangan lebih diarahkan pada jalur lingkar selatan Propinsi Jawa barat.

Dengan populasi ternak sebanyak 309.609 ekor (thn 2009) yang didukung oleh luas areal pertanian (padi) 1.950.203 ha (thn 2009), tentu merupakan merupakan potensi besar untuk pengembangan lebih jauh usaha pembibitan ternak sapi potong. Pemerintah Daerah Propinsi Jawa Barat melalui Dinas Peternakan Propinsi telah melakukan pengembangan kawasan sentra pengembangan ternak sapi potong. Dimana salah satu wilayah pengembangan ternak sapi potong 
Bambang Winarso: Realisasi Kegiatan Program Daerah dalam Pengembangan Pembibitan Sapi Potong...

yang lebih dikonsentrasikan di wilayah lingkar selatan salah satunya adalah wilayah Sukabumi yang telah dilakukan sejak 5 tahun yang lalu (2007) yang berlokasi di Kecamatan Purabaya.

Program pengembangan tersebut merupakan program yang bersumber dari dana APBD I dimana sapi yang dikembangkan adalah jenis BX yang dikembangkan melalui kegiatan kelompok. Sebanyak 8 (delapan) kelompok telah terbentuk dalam satu kawasan pengembangan ternak sapi potong dan dari 8 (delapan) kelompok peternak tersebut telah terbentuk dalam satu wadah Gapoktan. Kegiatan yang telah dikembangkan diantaranya pengadaan kandang kolektif, pembuatan embung, pengadaan pakan dan saung pakan. Dalam rencananya wilayah ini akan dijadikan wilayah percontohan pengembangan ternak sapi potong dengan pola usaha pembibitan sebagai dominasinya. Informasi menunjukkan bahwa induk sapi betina dengan klasifikasi F2 maupun F3 masih mampu melahirkan pedet berkwalitas.

Selain wilayah Purabaya, wilayah lain yang menjadi wilayah pengembangan di wilayah Sukabumi adalah wilayah Surade, Ciemas yang mana di wilayah daerah tersebut telah banyak dikembangkan ternak sapi potong dengan pola usaha pembibitan dengan sistim pemeliharaan ternak dilakukan secara sistim ekstenif dengan cara digembalakan. Sementara daerah lainnya di luar Sukabuni adalah wilayah Tasikmalaya terutama daerah Cibalong. Di daerah ini juga telah berkembang usaha budidaya pembibitan ternak sapi potong. Dijelaskan pula bahwa model pengembangan ternak sapi potong yang ideal untuk mendukung usaha pembibitan adalah model tumpangsari antara pola pembibitan dan pola penggemukan, dimana perbandingan jumlah ideal adalah 6 untuk penggemukan berbanding 3 untuk pembibitan. Sementara pelaksanaan yang dilakukan dalam kasus SMD adalah 20 ekor untuk penggemukan berbanding 6 untuk pembibitan.

Disarankan bahwa dalam upaya pengembangan budidaya ternak sapi potong baik pembibitan maupun penggemukan seyogyanya perlu dikembangkan lembaga kredit mikro ditingkat desa terlebih dahulu. Hal ini bertujuan agar masyarakat terbiasa berhubungan dengan lembaga tersebut (bank). Dengan dibentuknya lembaga keuangan mikro di tingkat pedesaan dan membudayanya masyarakat untuk terbiasa berhubungan dengan lembaga perbankan, diharapkan masyarakat tidak lagi direpotkan dengan masalah agunan apabila mau berhubungan dengan bank.

Pemerintah Jawa Barat dalam upaya pengembangan ternak sapi potong juga sedang merintis kegiatan KCR (Kredit Cinta Rakyat) sebesar 165 milyar rupiah, yangmana sumber dananya berasal dari APBD I. Plafon kredit dengan tingkat bunga sebesar 8\%/thn tersebut maksimal sebesar 15 juta diperuntukkan usaha mikro, dan plafon maksimal sebesar 25 juta diperuntukkan bagi pengusaha skala kecil. Permasalahannya adalah bahwa alokasi dana pinjaman tersebut pelaksanaannya juga melibatkan pihak bank sebagai eksekutor, sehingga masalah agunan jadi kendala lagi. Untuk mengatasi hal tersebut pihak pemerintah daerah Provinsi jawa Barat sedang mengusahakan adanya lembaga penjaminan kredit tersebut yang akan diupayakan melalui lembaga asuransi.

Permasalahan dalam pengembangan populasi ternak sapi potong melalui kebijakan daerah tersebut adalah bahwa ternak pemerintah merupakan "barang modal" atau "asset" milik pemerintah yang tidak bisa dipinjamkan. Dengan kondisi yang demikian maka peternak yang mendapat bantuan ternak dari pemerintah daerah tersebut sifatnya adalah bagi hasil. Program selanjutnya yang akan ditempuh dalam rangka upaya meningkatkan populasi ternak sapi potong adalah kembali ke pembinaan kelompok dengan baik terutama kelompok dengan model SMD. Informasi menunjukkan bahwa belum ada format yang jelas untuk menggantikan format program SMD tersebut. 
Jurnal Penelitian Pertanian Terapan

Dalam upaya pengembangan kawasan peternakan di wilayah Propinsi Jawa Barat, seyogyanya didasarkan atas perencanaan yang bersumber dari peta tata ruang wilayah propinsi (RTRWP). Permasalahannya bahwa sampai saat ini peta tata ruang wilayah propinsi Jawa Barat belum ada masih menunggu dari masing-masing kabupaten. Mengingat dalam pengembangan kawasan budidaya ternak sapi potong maupun pengembangan ternak lainnya tidak semata-mata atas keberadaan masing-masing kabupaten, akan tetapi bisa melintasi antar wilayah kabupaten. Informasi menunjukkan bahwa dalam rencana pengembangan kawasan peternakan disesuaikan dengan rencana yang telah dibuat oleh Ditjend Peternakan dan Penyakit Hewan di pusat.

Ada 3(tiga) pewilayahan utama di Prop. Jawa Barat dalam usaha pengembangan ternak khususnya pengembangan ternak sapi potong yaitu (a) Kawasan "Ciayu Maja Kuning" yaitu wilayah Kab. Cirebon, Indramayu, Majalengka dan Kabupaten Kuningan, (b) Wilayah Priangan Barat (Bandung, Bogor, Subang, Purwakarta,dan Sukabumi) dan (c) Wilayah Priangan Timur yaitu meliputi Kab. Banjar, Ciamis, Tasikmalaya, Cianjur dan Kab.Garut. Pengembangan kawasan peternakan sapi potong khususnya di wilayah "Ciayu Maja Kuning" saat ini masih terkesan samarsamar dalam artikata belum ada pemantapan dalam pelaksanaan.

\section{KESIMPULAN}

PP No 25 ps 2 ayat 3, thn 2000 menunjukkan bahwa kewenangan khusus menyangkut perbibitan masih menjadi kewenangan pemerintah pusat. Kaitannya dengan masalah perbibitan Direktorat Perbibitan memiliki peranan yang strategis. Dalam era otonami daerah yang digulirkan sejak tahun 1999, maka respon daerah terhadap upaya pengembangan ternak sapi potong, khususnya perbibitan juga direspon secara beragam. Dalam upaya meningkatkan populasi ternak sapi potong, kebijakan yang ditempuh oleh Pemerintah Provinsi Jawa Timur, melalui Dinas Peternakan Provinsi Jawa Timur telah pencanangkan program "Berlian" (beranak lima juta ekor dalam satu tahun). Sementara di Bali pemerintah daerah sejak tahun 2009 telah mencanangkan Program Pengembangan Usaha Pertanian Teritegrasi (Simantri). Program yang didukung oleh SK Gubernur No. 1776 Thn 2011 tersebut tidak lain adalah merupakan sistem pertanian integrasi sebagai kelanjutan dari program Prima Tani dari Badan Litbang Pertanian/BPTP. Sementara di Jambi tampaknya masih mengandalkan program pusat yaitu Program Penjaringan Betina Produktif, Program Penambahan Induk Sapi Potong dan Program Pengadaan pejantan pemacek. Sedangkan di Jawa Barat Dalam hal pengembangan pembibitan sapi potong, kasus di Jawa Barat menunjukkan bahwa masih diperlukan penjajakan terhadap wilayah-wilayah potensial yang memiliki dukungan teknis maupun non teknis program yang ada dikenal dengan naman Program Ciayu Maja Kuning (Cirebon, Indramayu, Majalengka dan Kuningan) yang merupakan pengembangan wilayah bagian utara Jawa barat.

\section{DAFTAR PUSTAKA}

Anomimous, 2001; Pelaksanaan Desentralisasi dan Otonomi Daerah Kasus Tiga Kabupaten di Sulawesi Utara dan Gorontalo; Laporan Penelitian SMERU, Juli 2001.

Argama R., 2005; Pemberlakuan Otonomi Daerah dan Fenomena Pemekaran Wilayah Di Indonesia; Fakultas Hukum; Universitas Indonesia. 
Bambang Winarso: Realisasi Kegiatan Program Daerah dalam Pengembangan Pembibitan Sapi Potong...

Badan Perencanaan Pembangunan Provinsi Jawa Barat, 2012; Rancangan Rencana Kerja Pemerintah Daerah Provinsi Jawa Barat Tahun 2012.

Dinas Peternakan Propinsi Jawa Timur, 2011; Laporan tahunan

Dinas Peternakan Propinsi Jambi Tahun 2010; Laporan Tahunan

Dinas Peternakan Propinsi Bali, 2012; Laporan Tahunan

Inpres No.1 Tahun 2010 tentang Percepatan Pelaksanaan Pembangunan Nasional

Ketetapan Menteri Pertanian No.3755/KPts/HK.040/11/2010 Keberadaan Sapi Madura sebagai kekayaan plasmanutfah milik Indonesia.

Mayrowani H. dkk, 2004; Agribisnis Sapi Potong Rakyat di Provinsi Jawa Timur, dampak Krisis Moneter dan Implementasi Kebijakan Otonomi Daerah; Pusat Penelitian Sosial Ekonomi dan Kebijakan Pertanian; Badan Litbang Pertanian.

Samariyanto, 2004; Alternatif Kebijakan Perbibitan Sapi Potong Dalam Era Otonomi Daerah; Lokakarya Nasional Sapi Potong; Direktorat Jenderal Bina Produksi Peternakan.

Solly Lubis, 2003; Masalah-masalah Hukum Dalam Pelaksanaan Otonomi Daerah; Makalah Seminar Pembangunan Hukum Nasional VIII; Penegakan Hukum Dalam Era Pembangunan Berkelanjutan; Badan Pembinaan Hukum Nasional; Departemen Kehakiman dan Hak Asasi Manusia Republik Indonesia.

SK Gubernur Bali No. 1776 Thn 2011 Tentang Simantri (Sistem Pertanian Terintegrasi) 